\title{
Canopy cover negatively affects arboreal ant species richness in a tropical open habitat
}

\author{
A. C. M. Queiroz ${ }^{a, b *}$ and C. R. Ribas ${ }^{a}$ \\ a'Laboratório de Ecologia de Formigas, Setor de Ecologia e Conservação, Departamento de Biologia, \\ Universidade Federal de Lavras - UFLA, CP 3037, CEP 37200-000, Lavras, MG, Brazil

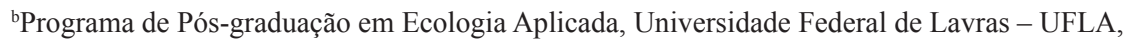 \\ CEP 37200-000, Lavras, MG, Brazil \\ *e-mail: queirozacm@gmail.com
}

Received: January 29, 2015 - Accepted: September 11, 2015 - Distributed: November 30, 2016

(With 3 figures)

\begin{abstract}
We tested the hypothesis of a negative relationship between vegetation characteristics and ant species richness in a Brazilian open vegetation habitat, called candeial. We set up arboreal pitfalls to sample arboreal ants and measured the following environmental variables, which were used as surrogate of environmental heterogeneity: tree richness, tree density, tree height, circumference at the base of the plants, and canopy cover. Only canopy cover had a negative effect on the arboreal ant species richness. Vegetation characteristics and plant species composition are probably homogeneous in candeial, which explains the lack of relationship between other environmental variables and ant richness. Open vegetation habitats harbor a large number of opportunistic and generalist species, besides specialist ants from habitats with high temperatures. An increase in canopy cover decreases sunlight incidence and may cause local microclimatic differences, which negatively affect the species richness of specialist ants from open areas. Canopy cover regulates the richness of arboreal ants in open areas, since only few ant species are able to colonize sites with dense vegetation; most species are present in sites with high temperature and luminosity. Within open vegetation habitats the relationship between vegetation characteristics and species richness seems to be the opposite from closed vegetation areas, like forests.
\end{abstract}

Keywords: environmental heterogeneity, microclimate, vegetation characteristics, hierarchical partitioning, candeia.

\section{A cobertura de dossel afeta negativamente a riqueza de formigas arborícolas em um hábitat tropical aberto}

\begin{abstract}
Resumo
Nós testamos a hipótese de que há uma relação negativa entre as características da vegetação e a riqueza de espécies de formigas em habitats abertos como o candeial. Para isto, nós instalamos pitfalls arborícolas para a captura de formigas e mensuramos as seguintes variáveis ambientais: riqueza de árvores, densidade de árvores, altura de árvores, circunferência basal das plantas e cobertura de dossel. Somente a cobertura de dossel apresentou efeito negativo na riqueza de formigas arborícolas. Provavelmente, as características da vegetação e a composição de espécies de plantas são mais homogêneas no candeial, o que explica a ausência de relação entre a riqueza de formigas e as outras variáveis ambientais. Formações abertas abrigam um grande número de espécies oportunistas e generalistas, além de formigas especialistas de climas quentes. $\mathrm{O}$ aumento na cobertura de dossel diminui a incidência solar o que pode causar diferenças microclimáticas que afetam negativamente as espécies de formigas especialistas de hábitats abertos. A cobertura de dossel regula a riqueza de espécies de formigas arborícolas em áreas abertas e poucas espécies nestes locais estão aptas a colonizar locais com a vegetação densa. Assim, a maioria das espécies estão presentes em locais com alta temperatura e luminosidade. Em outras palavras, em hábitats de vegetação aberta a relação entre características da vegetação e a riqueza de espécies pode ser oposta em comparação ao que é encontrado em áreas que apresentam a vegetação mais fechada, como florestas.
\end{abstract}

Palavras-chave: heterogeneidade ambiental, microclima, características da vegetação, partição hierárquica, candeia. 


\section{Introduction}

Several ecological processes act on the determination and regulation of species richness in space and time (Ricklefs and Schluter, 1993). Those related to environmental heterogeneity, for example, are usually related to species richness (Tews et al., 2004; Stein et al., 2014). In ecological studies of ant communities, environmental heterogeneity is frequently estimated by parameters of the local vegetation, such as plant richness and density (Ribas et al., 2003), tree size (Fonseca and Benson, 2003; Campos et al., 2006; Costa et al., 2011), or canopy cover (Kalif et al., 2001; Philpott et al., 2006), which are characteristics related to quality and availability of resources or better microclimatic conditions for ant species.

In most of the above-cited studies, and also in studies with other taxa, the authors found positive relationships between vegetation characteristics (surrogates of heterogeneity) and species richness (Tews et al., 2004; Stein et al., 2014). The positive relationship between variables that represent environmental heterogeneity and species richness is more common, because they are associated with mechanisms that promote species coexistence, persistence and diversification. Moreover, this correlation may also be a result of the dependence of both taxa on other environmental variables, such as tree richness (Stein et al., 2014). Studies on ant communities in several vegetation types suggest that there may be a positive (Ribas et al., 2003; Ribas and Schoereder, 2007), negative (Lassau and Hochuli, 2004; Schmidt et al., 2013) or neutral relationship (Ribas and Schoereder, 2007; Schmidt et al., 2013) between species richness and habitat heterogeneity (Stein et al., 2014).

A negative relationship between species richness and environmental variables, representing habitat heterogeneity was found in some open vegetation habitats (Stein et al., 2014). This might be explained by a decrease in the number of species sensitive to warmer microclimate conditions in open vegetation habitats (Pino et al., 2000; Desrochers et al., 2011). Open-area species can replace shade-adapted species in disturbed forests (King et al., 1998; Madureira et al., 2012) and these species do not perform the same functions (Barbosa et al., 2015). Furthermore, there is a correlation between the thermal tolerance of ants and the environment in which they occur, as there are differences in temperatures of optimal foraging among species in the same community (Dunn et al., 2009). Dominant species can forage in their optimal temperature ranges and subordinates in suboptimal, which usually occur in warmer temperatures in open habitats (Cerdá et al., 2013). Moreover, studies with small spatial scales might also present negative relationships between environmental heterogeneity and species richness due to the dominance of few species in heterogeneous habitats (Stein et al., 2014).

Most studies regarding the relationship between species richness and environmental heterogeneity have been carried out in forest habitats that have diverse vegetation characteristics and dense vegetation. Hence, there are fewer studies with ant diversity in Brazilian tropical open habitats, such as fields (but see Rosumek, 2008; Lopes et al., 2012; Viana-Silva and Jacobi, 2012). It is likely that, in these habitats, differences in species richness patterns may remain unnoticed, pointing to the need for studies on ant diversity in open habitats (Klimes et al., 2012). In this study we assessed environmental variables in open environments, that are known to regulate the richness of arboreal ants in other habitats, such as forests. We hypothesized an inversion in the relationship between ant richness and habitat heterogeneity in open vegetation habitats due to the loss of hot climate tolerant species. Therefore, we tested the hypothesis of a negative relationship between habitat heterogeneity and ant species richness in a tropical open vegetation habitat.

\section{Material and Methods}

\subsection{Study area}

The present study was carried out in October 2011 in Ibitipoca State Park (2142'51.19'S 4353'48.93”W), municipality of Lima Duarte, state of Minas Gerais, southeastern Brazil. The park encompasses several vegetation types, such as campos rupestres (rupestrian vegetation on rocky outcrops), high-altitude grasslands, riparian forests, and cloud forests (Dias et al., 2002). The predominant vegetation is the candeia forest (hereafter candeial), an open vegetation habitat, which represents $24 \%$ of the park's area that is dominated by Eremanthus erythropappus (DC.) McLeish. (Asteraceae), with some other species of shrubs (Dias et al., 2002). The local climate is classified as highland tropical, characterized by a mild and rainy summer and a dry winter. The average annual temperature is $18.9^{\circ} \mathrm{C}$ and the annual rainfall is approximately $1,395 \mathrm{~mm}$.

Sampling took place in a candeial with approximately 2 ha. In addition to the predominance of E. erythropappus with low and medium sizes (Oliveira-Filho and Fluminhan-Filho, 1999), most of which belong to the genus Eremanthus (Scolforo et al., 2007) and are considered pioneer species that grow on poor soils in campos rupestres and high-altitude grasslands (Pérez et al., 2004; Santos et al., 2011).

\subsection{Sampling}

We sampled ants at 30 sites $(\mathrm{N}=30), 20 \mathrm{~m}$ apart from each other. To do this, we set up one arboreal pitfall in each sampling point (see Ribas et al., 2003) without a bait at each site and left it open for $48 \mathrm{~h}$. We identified the ant genera with taxonomic keys (Bolton, 1994; Palacio and Fernández, 2003) and compared with vouchers to separate the morphospecies. Specimens were deposited in the collection of the Ant Ecology Laboratory at the Universidade Federal de Lavras - UFLA.

In addition, we set up a $6 \times 6-\mathrm{m}$ plot around each tree with a pitfall, and measured the following variables that represent the amount and heterogeneity of resources and variation of conditions for ants: density, richness, height 
and circumference at the base $(\mathrm{CAB})$ of trees and shrubs that had $\mathrm{CAB} \geq 10 \mathrm{~cm}$, and canopy cover.

We counted all individual trees and shrubs within each plot to calculate tree density, as well as the number of tree and shrub morphospecies. We also estimated the height and measured the circumference at the base of the same trees and shrubs. In order to measure canopy cover, we took a hemispherical photograph of the canopy, using a camera with a fisheye objective positioned at $1.5 \mathrm{~m}$ above the ground and as close as possible to the tree with the pitfall. We analyzed the photographs in Gap Light Analyzer (GLA) software (Frazer et al., 1999), in order to calculate the canopy cover percentage (Engelbrecht and Herz, 2001).

\subsection{Data analysis}

We used a species extrapolation curve to estimate the arboreal ant diversity in candeial (Chao and Jost, 2012) with iNEXT online: interpolation and extrapolation (Hsieh et al., 2013). We used hierarchical partitioning to assess the independent effects of the five environmental variables (tree richness, tree density, plant height, circumference at the base, and canopy cover) on the species richness of arboreal ants (Chevan and Sutherland, 1991). Hierarchical partitioning is a multiple regression technique in which all possible linear models are considered to identify the main factors that effectively influence the response variable (Chevan and Sutherland, 1991; MacNally, 2000). The model assumed a Poisson distribution, which is suitable for count data. The significance of each independent effect was estimated through randomization with 1000 permutations (MacNally, 2000). Data analysis was carried out with the hier.part package (Walsh and MacNally, 2013) of R 3.0.1 (R Development Core Team, 2013).

\section{Results}

We collected 23 ant species of eight genera. The subfamilies found in the study were Formicinae and Myrmicinae, represented by nine and eleven species, respectively, and Pseudomyrmecinae, with three species. The most common genus was Camponotus with eight species. Camponotus crassus Santschi, 1922 and Camponotus sp. 4 were the most frequently captured species (Table 1). The average richness and standard deviation was $1.77 \pm 1.38$ ants per pitfall. With a doubled sampling effort we would capture approximately seven more species (Figure 1).

The average and standard deviation values of the environmental variables per plot were: plant density $0.21 \pm 0.11$ plant $/ \mathrm{m}^{2}$, plant species $3.03 \pm 1.77 \mathrm{spp}$., tree height $2.99 \pm 0.82 \mathrm{~m}$, circumference at the base $22.53 \pm 7.17 \mathrm{~cm}$, and canopy cover $26.60 \pm 12.04 \%$. Only canopy cover had a significant and negative effect on the arboreal ant species richness $(\mathrm{p}<0.05 ; \mathrm{Z}=3.42)$ (Figure 2, Figure 3). Other variables: plant density ( $p>0.05$; $Z=1.14)$, plant richness ( $p>0.05 ; Z=-0.19)$, tree height $(p>0.05 ; Z=-0.32)$, and circumference at the base of plants $(p>0.05 ; Z=-0.27)$ did not explain the variation in the species richness of arboreal ants.
Table 1. Species of arboreal ants sampled with arboreal pitfall traps $(\mathrm{N}=30)$ in the candeial of Ibitipoca State Park, Lima Duarte, Minas Gerais state, Brazil.

\begin{tabular}{|c|c|c|}
\hline Subfamilies & Species & $\begin{array}{c}\text { Frequency } \\
(\%)\end{array}$ \\
\hline \multirow[t]{12}{*}{ Formicinae } & Brachymyrmex sp. 1 & 0.033 \\
\hline & Camponotus crassus & 0.333 \\
\hline & Santschi, 1922 & \\
\hline & Camponotus melanoticus & 0.133 \\
\hline & Santschi, 1939 & \\
\hline & Camponotus rufipes & 0.100 \\
\hline & Fabricius, 1775 & \\
\hline & Camponotus sp. 1 & 0.033 \\
\hline & Camponotus sp. 2 & 0.033 \\
\hline & Camponotus sp. 3 & 0.033 \\
\hline & Camponotus sp. 4 & 0.200 \\
\hline & Camponotus sp. 5 & 0.067 \\
\hline \multirow[t]{12}{*}{ Myrmicinae } & Cephalotes depressus & 0.067 \\
\hline & Klug, 1824 & \\
\hline & Cephalotes sp. 1 & 0.033 \\
\hline & Crematogaster sp. 1 & 0.067 \\
\hline & Nesomyrmex sp. 1 & 0.033 \\
\hline & Pheidole sp. 1 & 0.033 \\
\hline & Pheidole sp. 2 & 0.033 \\
\hline & Pheidole sp. 3 & 0.033 \\
\hline & Solenopsis gr. geminata & 0.033 \\
\hline & Solenopsis sp. 1 & 0.167 \\
\hline & Solenopsis sp. 2 & 0.100 \\
\hline & Solenopsis sp. 3 & 0.033 \\
\hline \multirow[t]{4}{*}{ Pseudomyrmicinae } & Pseudomyrmex gracilis & 0.033 \\
\hline & Pseudomvrmex termitarius & 0.067 \\
\hline & Smith, F., 1855 & 0.001 \\
\hline & Pseudomyrmex sp. 1 & 0.067 \\
\hline Total & 23 & \\
\hline
\end{tabular}

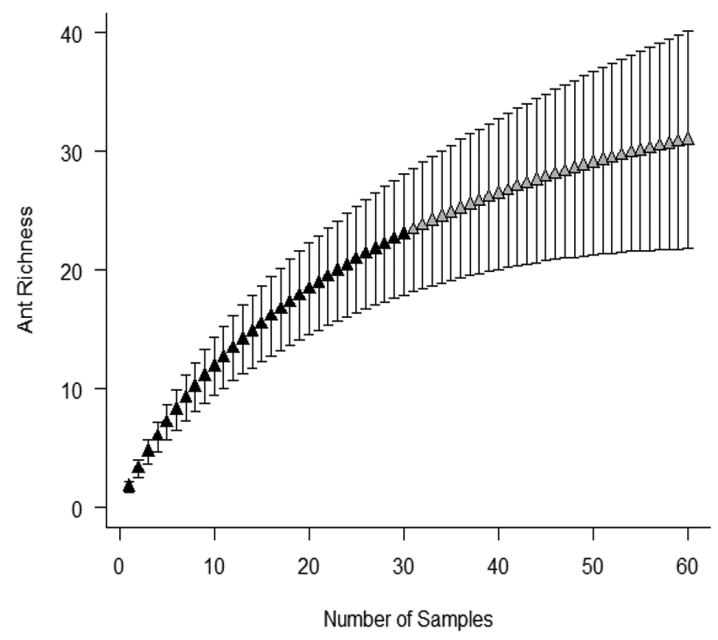

Figure 1. Extrapolation curve of arboreal ant species in candeial. Black symbols represent sampled ants and the grey symbols represent the extrapolated ant species. 


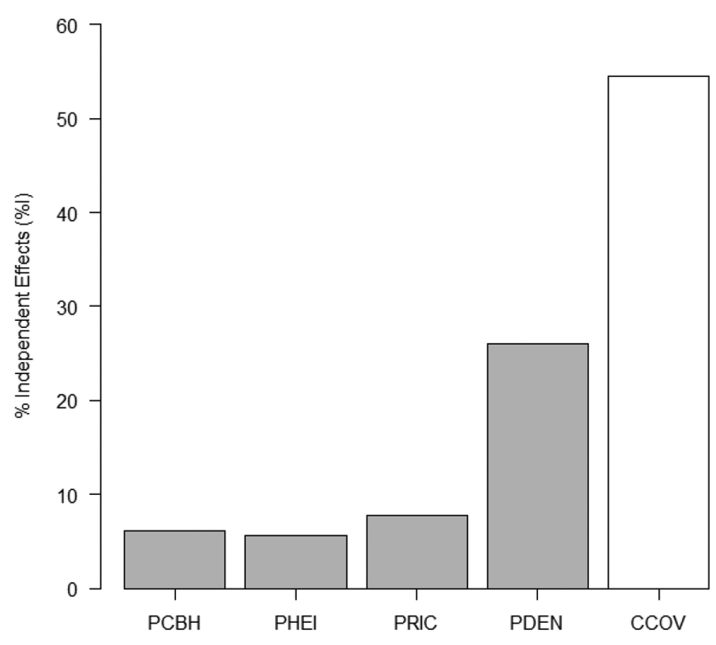

Figure 2. Distribution of the percentage of independent effects of five environmental variables on the ant species richness of arboreal species. The white bar represents negative significant effects $(\mathrm{P}<0.05)$, as determined by randomization tests. Environmental variables include plant circumference at the base (PCAB), plant height (PHEI), plant richness (PRIC), plant density (PDEN) and canopy cover (CCOV).

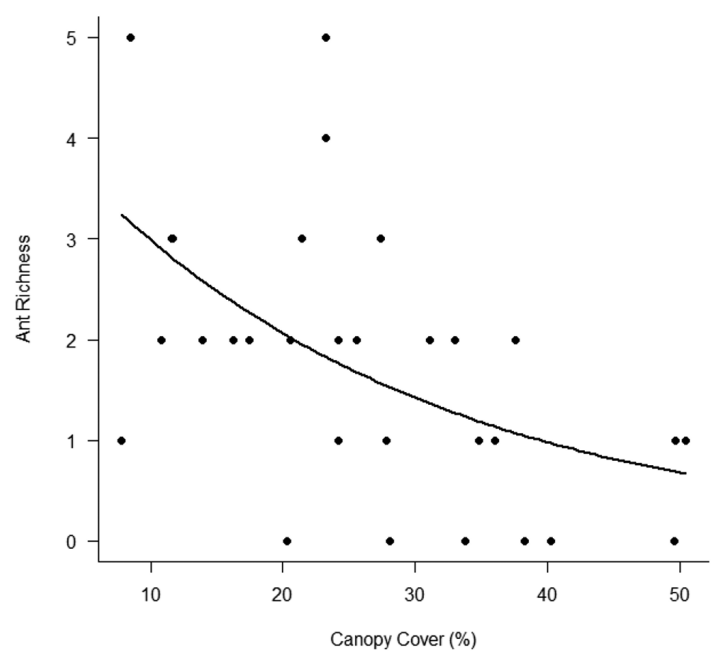

Figure 3. Relationship between ant richness and canopy cover $(\mathrm{N}=30)$ in the candeial of Ibitipoca State Park, Lima Duarte, Minas Gerais state, Brazil.

\section{Discussion}

We confirmed our hypothesis that arboreal ant species richness is negatively related to canopy cover, a vegetation variable that we used as surrogate for habitat heterogeneity. A low canopy cover allows greater sunlight incidence and an increase in temperature, favoring ants that are adapted to open vegetation habitats.

Captured arboreal ants that live in the candeial are frequently found in naturally open vegetation habitats (e.g. rocky grasslands, Costa et al., 2015) or deforested areas. The arboreal ant species found in the present study (Camponotus spp., Cephalotes spp., and Pseudomyrmex spp.) belong to genera and subfamilies that are frequently associated with plants (Oliveira and Freitas, 2004), including Eremanthus erythropappus (Rosumek, 2008), the dominant plant species in the study area. Ants from the genus Camponotus are frequently found in the candeial soil and easily access trees (Rosumek, 2008). Comparing ant communities from three vegetation types in the same study area, Lopes et al. (2012) found a lower number of cryptic species and a larger number of generalists in the rocky outcrops (dominated by candeia), areas that have less litter accumulation and a high number of ant genera commonly associated with plants that have extrafloral nectaries.

Some species found in the present study, such as Camponotus rufipes and Solenopsis gr. geminata, are very common generalists and opportunists in many habitats, including those with open vegetation characteristics, such as the candeial (Brandão et al., 2000; Neves et al., 2010; Dáttilo et al., 2011). These ants explore a wide variety of resources, competing with specialist species (Didham, 1997; Silvestre and Silva, 2001). E. erythropappus may be an important resource for ant species (Rosumek, 2008). It is possible that the candeia has some food source at the lower part of the calyx, which attracts ants (Rosumek, 2008). At this part of the plant, the presence of membracids is common (pers. obs.), which may have trophobiotic relationships with some ant species. Hence, ants (e.g. Camponotus spp.) may be attracted to E. erythropappus by food resources, on which they participate in opportunistic interactions (Chamberlain and Holland, 2009; Rosumek et al., 2009). Furthermore, senescent stem-galls in these trees are also adding shelter resource for arboreal ants (e.g. Crematogaster spp.) (Almeida et al., 2014).

Among the studied variables, we found only a negative relationship between arboreal ant richness and canopy cover. With few exceptions (e.g. Lassau and Hochuli, 2004), most studies point to positive relationships between species richness and environmental heterogeneity (Tews et al., 2004; Cramer and Willig, 2005; Basset et al., 2012; Stein et al., 2014). For ants, a higher tree density and richness may lead to higher abundance and diversity of resources and, ultimately, result in higher species richness (Ribas et al., 2003; Ribas and Schoereder, 2007; Dejean et al., 2008; Gomes et al., 2010). However, the strength of the relationships between vegetation variables and species richness may change according to the landscape (Powell et al., 2011).

In the present study, there was no relationship between ant richness and plant density. The plant density in the candeial was much lower when comparing to another Cerrado vegetation types (Ribas et al., 2003). The lack of relationship between plant richness and ant richness in the candeial may be explained by the low plant species diversity in this environment. This small number of plant species does not considerably increase resource variety for ants; therefore, the quality of resources does not result 
in higher ant richness. The arboreal ant community is strongly affected by plants that offer them resources (Dejean et al., 2008). However, another important factor for the ant community structure is the relationship between ants and some plant species or genera. In the candeial, the plant species that provide resources for ants is composed of a small group of shrubs and trees (Klimes et al., 2012).

Our results do not suggest that plant size is a factor regulating ant richness. Larger trees (those with high height and $\mathrm{CAB}$ ) do also offer more resources, which are important for structuring arboreal ant communities (Fonseca and Benson, 2003; Campos et al., 2006; Costa et al., 2011; Klimes et al., 2012). In the candeial, generalist ant species, which have a broad distribution in the area and move easily between canopy and soil (Rosumek, 2008), may interfere in resource use and site occupation by specialized species, which are exclusively arboreal and would potentially colonize larger trees (Gomes et al., 2010).

Open habitats usually harbor a large number of opportunistic and generalist species, besides specialist ant species from sites with high temperatures (Lassau and Hochuli, 2004). The increase in canopy cover, from 7.8 to $50.43 \%$, observed in the present study caused a decrease in sunlight incidence, resulting in local microclimatic changes (for instance in humidity and temperature), which may have negatively affected specialist ant species from open areas. This occurs because these species have an optimum temperature range for foraging and most of them forage in warmer locations (Cerdá et al., 2013). However, in an open environment, where there are predominantly shrubs, as in the candeial, temperature can be stressful. In this environment the subordinate ants forage in higher temperatures and demonstrate greater tolerance to temperature changes than dominant species (Cerdá et al., 2013). In some places in the candeial (some of our plots), e.g. in those microhabitats with high canopy cover, generalist and opportunistic ant species are reduced or excluded, as they are better adapted to the incidence of high sunlight and high temperature of open areas (Schoereder et al., 2004; Binckley and Resentarits, 2009; Pike et al., 2011). Some of the negative relationships between environmental heterogeneity and species richness may also occur due to increases in energy costs in the mobility of animals in denser habitats. These negative relationships are also commonly found at small spatial scales (Stein et al., 2014).

On the other hand, species that are associated with dense vegetation may have been excluded from our study area because they are more sensitive to the severe environmental conditions of these areas (King et al., 1998). Although most candeial species are able to tolerate high temperatures and low water and organic matter availability, they cannot colonize sites with high canopy cover (Lassau and Hochuli, 2004), whereas specific ants from dense vegetation are probably better adapted to environments with high humidity and low temperature (Schmidt et al., 2013). Thus, microhabitats with a higher canopy cover should contain just a fewer species of specialized ants. These ants may also be more successful in colonizing forested areas (as the cloud forest located in the park) than open areas with high canopy cover.

Concluding, canopy cover regulates the species richness of arboreal ants in this open vegetation habitat, since among most generalist and opportunistic species, only a few are able to colonize areas with higher canopy cover. Furthermore, it is possible to infer that in open vegetation habitats, such as those studied here, the relationship between environmental heterogeneity and species richness may be the inverse of that found in some savannas and forests, which reinforces the need for studies in other kinds of open tropical vegetation. Studies in open areas, that focus on detecting this pattern, are crucial because tropical open habitats have been less studied than forests in community ecology. It is very important to detect this inverse pattern in open areas because we cannot simply use the same variables that are used for forests, which would lead us to wrong decisions for management and conservation in those areas.

\section{Acknowledgements}

The present study was carried out during the courses Field Ecology I and II (PEC 506 and PEC 521) of the Programa de Pós-Graduação em Ecologia Aplicada, Universidade Federal de Lavras. We thank K.P.G. Leal, R.M. Ribeiro, E. Teixeira, and J. Tuller for the help in fieldwork. F.M. França, E. Jimenez-Soto, F. Schmidt, L. Zanella, and two anonymous referees gave invaluable suggestions to early versions of this manuscript and revised the English. Instituto Estadual de Florestas de Minas Gerais (IEF-MG) and Universidade Federal de Lavras (UFLA) provided us with logistic support. A.C.M. Queiroz received a scholarship from the Coordenação de Aperfeiçoamento de Pessoal de Nível Superior (Capes).

\section{References}

ALMEIDA, M.F.B., SANTOS, L.R. and CARNEIRO, M.A.A., 2014. Senescent stem-galls in trees of Eremanthus erythropappus as a resource for arboreal ants. Revista Brasileira de Entomologia, vol. 58, no. 3, pp. 265-272. http://dx.doi.org/10.1590/S008556262014000300007 .

BARBOSA, B.C., FAGUNDES, R., SILVA, L.F., TOFOLI, J.F.V., SANTOS, A.M., IMAI, B.Y.P., GOMES, G.G., HERMIDORFF, M.M. and RIBEIRO, S.P., 2015. Evidences that human disturbance simplify the ant fauna associated a Stachytarpheta glabra Cham. (Verbenaceae) compromising the benefits of ant-plant mutualism. Brazilian Journal of Biology = Revista Brasileira de Biologia, vol. 75, no. 1, pp. 58-68. http://dx.doi.org/10.1590/1519-6984.07213. PMid:25945621

BASSET, Y., CIZEK, L., CUÉNOUD, P., DIDHAM, R.K., GUILHAUMON, F., MISSA, O., NOVOTNY, V., ØDEGAARD, F., ROSLIN, T., SCHMIDL, J., TISHECHKIN, A.K., WINCHESTER, N.N., ROUBIK, D.W., ABERLENC, H.P., BAIL, J., BARRIOS, H., BRIDLE, J.R., CASTAÑO-MENESES, G., CORBARA, B., CURLETTI, G., ROCHA, W.D., BAKKER, D., DELABIE, J.H.C., DEJEAN, A., FAGAN, A.L., FLOREN, A., KITCHING, R.L., MEDIANERO, E. and MILLER, S.E., 2012. Arthropod diversity 
in a Tropical Forest. Science, vol. 338, no. 6113, pp. 1481-1484. http://dx.doi.org/10.1126/science.1226727. PMid:23239740.

BINCKLEY, C.A. and RESENTARITS, W.J., 2009. Spatial and temporal dynamics of habitat selection across canopy gradients generates patterns of species richness and composition in aquatic beetles. Ecological Entomology, vol. 34, no. 4, pp. 457-465. http:// dx.doi.org/10.1111/j.1365-2311.2008.01069.x.

BOLTON B., 1994. Identification guide to the ant genera of the World. Harvard: Harvard University Press.

BRANDÃO, C.R.F., SILVA, R.R. and DELABIE, J.H.C., 2000. Neotropical ants (Hymenoptera) functional groups: nutritional and applied implications. In: A.R. PANIZZI and J.R.P. PARRA. Insect bioecology and nutrition for integrated pest management. Boca Raton: CRC Press, pp. 213-236.

CAMPOS, R.I., VASCONCELOS, H.L., RIBEIRO, S.P., NEVES, F.S. and SOARES, J.P., 2006. Relationship between tree size and insect assemblages associated with Anadenanthera macrocarpa. Ecography, vol. 29, no. 3, pp. 442-450. http://dx.doi. org/10.1111/j.2006.0906-7590.04520.x.

CERDÁ, X., ARNAN, X. and RETANA, J., 2013. Is competition a significant hallmark of ant (Hymenoptera: Formicidae) ecology? Myrmecological News, vol. 18, pp. 131-147.

CHAMBERLAIN, S.A. and HOLLAND, J.N., 2009. Quantitative synthesis of context dependency in ant-plant protection mutualisms. Ecology, vol. 90, no. 9, pp. 2384-2392. http://dx.doi.org/10.1890/081490.1. PMid:19769117.

CHAO, A. and JOST, L., 2012. Coverage-based rarefaction and extrapolation: standardizing samples by completeness rather than size. Ecology, vol. 93, no. 12, pp. 2533-2547. http://dx.doi. org/10.1890/11-1952.1. PMid:23431585.

CHEVAN, A. and SUTHERLAND, M., 1991. Hierarchical partitioning. Journal of the American Statistical Association, vol. 45 , pp. $90-96$.

COSTA, F.V., NEVES, F.S., SILVA, J.O. and FAGUNDES, M., 2011. Relationship between plant development, tannin concentration and insects associated with Copaifera langsdorffii (Fabaceae). Arthropod-Plant Interactions, vol. 5, no. 1, pp. 9-18. http://dx.doi. org/10.1007/s11829-010-9111-6.

COSTA, F.V., MELLO, R., LANA, T.C. and NEVES, F.S., 2015. Ant fauna in megadiverse mountains: a checklist for the Rocky Grasslands. Sociobiology, vol. 62, no. 2, pp. 228-245. http:// dx.doi.org/10.13102/sociobiology.v62i2.228-245.

CRAMER, M.J. and WILLIG, M.R., 2005. Habitat heterogeneity, species diversity and null models. Oikos, vol. 108, no. 2, pp. 209-218. http://dx.doi.org/10.1111/j.0030-1299.2005.12944.x.

DÁTTILO, W., SIBINEL, N., FALCÃO, J.C.F. and NUNES, R.V., 2011. Mirmecofauna em um fragmento de Floresta Atlântica Urbana no Município de Marília, SP, Brasil. Bioscience Journal, vol. 27, pp. 494-504.

DEJEAN, A., DJIÉTO-LORDON, C., CÉRÉGHINO, R. and LEPONCE, M., 2008. Ontogenetic succession and the ant mosaic: an empirical approach using pioneer trees. Basic and Applied Ecology, vol. 9, no. 3, pp. 316-323. http://dx.doi.org/10.1016/j. baae.2007.03.001.

DESROCHERS, R.E., KERR, J.T. and CURRIE, D.J., 2011. How, and how much, natural cover loss increases species richness. Global Ecology and Biogeography, vol. 20, no. 6, pp. 857-867. http://dx.doi.org/10.1111/j.1466-8238.2011.00658.x.
DIAS, H.C.T., FERNANDES-FILHO, E.I., SCHAEFER, C.E.G.R., FONTES, L.E.F. and VENTORIM, L.B., 2002. Geoambientes do Parque Estadual do Ibitipoca, município de Lima DuarteMG. Revista Árvore, vol. 26, no. 6, pp. 777-786. http://dx.doi. org/10.1590/S0100-67622002000600014.

DIDHAM, R.K., 1997. An overview of invertebrate responses to forest fragmentation, In: A.D. WATT, N.E. STORK and M.D. HUNTER. Forests and insects. London: Chapman \& Hall, pp. 303-320.

DUNN, R.R., AGOSTI, D., ANDERSEN, A.N., ARNAN, X., BRUHL, C.A., CERDÁ, X., ELLISON, A.M., FISHER, B.L., FITZPATRICK, M.C., GIBB, H., GOTELLI, N.J., GOVE, A.D., GUENARD, B., JANDA, M., KASPARI, M., LAURENT, E.J., LESSARD, J.P., LONGINO, J.T., MAJER, J.D., MENKE, S.B., MCGLYNN, T.P., PARR, C.L., PHILPOTT, S.M., PFEIFFER, M., RETANA, J., SUAREZ, A.V., VASCONCELOS, H.L., WEISER, M.D. and SANDERS, N.J., 2009. Climatic drivers of hemispheric asymmetry in global patterns of ant species richness. Ecology Letters, vol. 12, no. 4, pp. 324-333. http:// dx.doi.org/10.1111/j.1461-0248.2009.01291.x. PMid:19292793.

ENGELBRECHT, B.M.J. and HERZ, H.M., 2001. Evaluation of different methods to estimate understorey light conditions in tropical forests. Journal of Tropical Ecology, vol. 17, no. 2, pp. 207-224. http://dx.doi.org/10.1017/S0266467401001146.

FONSECA, C.R. and BENSON, W.W., 2003. Ontogenetic succession in Amazonian ant trees. Oikos, vol. 102, no. 2, pp. 407-412. http://dx.doi.org/10.1034/j.1600-0579.2003.12021.x.

FRAZER, G.W., CANHAM, C.D. and LERTZMAN, K.P., 1999. Gap Light Analyzer (GLA): imaging software to extract canopy structure and gap light transmission indices from truecolour fisheye photographs, user manual and program documentation. Burnaby: Simon Fraser University.

GOMES, J.P., IANNUZZI, L. and LEAL, I.R., 2010. Resposta da comunidade de formigas aos atributos dos fragmentos e da vegetação em uma paisagem da Floresta Atlântica Nordestina. Neotropical Entomology, vol. 39, no. 6, pp. 898-905. http://dx.doi. org/10.1590/S1519-566X2010000600008. PMid:21271055.

HSIEH, T.C., MA, K.H. and CHAO, A., 2013 [viewed 13 December 2013]. iNEXT online: interpolation and extrapolation. Version 1.3.0 [online]. Software. Available from: http://chao.stat.nthu. edu.tw/blog/software-download/

KALIF, K.A.B., AZEVEDO-RAMOS, C., MOUTINHO, P. and MALCHER, S.A.O., 2001. The effect of logging on the ground-foraging ant community in eastern Amazonia. Studies on Neotropical Fauna and Environment, vol. 36, no. 3, pp. 215-219. http://dx.doi.org/10.1076/snfe.36.3.215.2119.

KING, J.R., ANDERSEN, A.N. and CUTTER, A.D., 1998. Ants as bioindicators of habitat disturbance: validation of the functional group model for Australia's humid tropics. Biodiversity and Conservation, vol. 7, no. 12, pp. 1627-1638. http://dx.doi. org/10.1023/A:1008857214743.

KLIMES, P., IDIGEL, C., RIMANDAI, M., FAYLE, T.M., JANDA, M., WEIBLEN, G.D. and NOVOTNY, V., 2012. Why are there more arboreal ant species in primary than in secondary tropical forests? Journal of Animal Ecology, vol. 81, no. 5, pp. 1103-1112. http://dx.doi.org/10.1111/j.1365-2656.2012.02002.x. PMid:22642689.

LASSAU, S.A. and HOCHULI, D.F., 2004. Effects of habitat complexity on ant assemblage. Ecography, vol. 27, no. 2, pp. 157-164. http://dx.doi.org/10.1111/j.0906-7590.2004.03675.x. 
LOPES, J.F.S., HALLACK, N.M.R., SALES, T.A., BRUGGER, M.S., RIBEIRO, L.F., HASTENREITER, I.N. and CAMARGO, R.S., 2012. Comparison of the ant assemblages in three phytophysionomies: Rocky Field, Secondary Forest, and Riparian Forest - A Case Study in the State Park of Ibitipoca, Brazil. Psyche. Article ID, vol. 928371, pp. 1-7.

MACNALLY, R., 2000. Regression and model-building in conservation biology, biogeography and ecology: the distinction between - and reconciliation of - 'predictive' and 'explanatory' models. Biodiversity and Conservation, vol. 9, no. 5, pp. 655-671. http://dx.doi.org/10.1023/A:1008985925162.

MADUREIRA, M.S., SOBRINHO, T.G. and SCHOEREDER, J.H., 2012. Why do ant species occur in the matrix and not in the forests? Invasion from other habitats or expansion from forest gaps (Hymenoptera: Formicidae). Sociobiology, vol. 59, pp. 1-13.

NEVES, F.S., BRAGA, R.F., ESPÍRITO-SANTO, M.M., DELABIE, J.H.C., FERNANDES, G.W. and SÁNCHEZ-AZOFEIFA, G.A., 2010. Diversity of arboreal ants in a Brazilian torpical dry forest: effects of seasonality and successional stage. Sociobiology, vol. 56 , pp. 1-18.

OLIVEIRA, P.S. and FREITAS, A.V.L., 2004. Ant-plant-herbivore interactions in the neotropical cerrado savanna. Naturwissenschaften, vol. 91 , no. 12, pp. 557-570. http://dx.doi.org/10.1007/s00114004-0585-x. PMid:15551026.

OLIVEIRA-FILHO, A.T. and FLUMINHAN-FILHO, M., 1999. Ecologia da vegetação do Parque Florestal Quedas do Rio Bonito. Cerne, vol. 5, pp. 51-64.

PALACIO, E.E. and FERNÁNDEZ, F., 2003. Claves para las subfamilias y géneros. In: F. FERNÁNDEZ. Introducción a las hormigas de la region Neotropical. Bogotá: Instituto de Investigación de Recursos Biológicos Alexander von Humboltm, pp. 233-260.

PÉREZ, J.F.M., SCOLFORO, J.R.S., OLIVEIRA, A.D., MELLO, J.M., BORGES, L.F.R. and CAMOLESI, J.F., 2004. Sistema de manejo para a candeia - Eremanthus erythropappus (DC.) Macleish: a opção do sistema de corte seletivo. Cerne, vol. 10, pp. 257-273.

PHILPOTT, S.M., PERFECTO, I. and VANDERMEER, J., 2006. Effects of management intensity and season on arboreal ant diversity and abundance in coffee agroecosystems. Biodiversity and Conservation, vol. 15, no. 1, pp. 139-155. http://dx.doi. org/10.1007/s10531-004-4247-2.

PIKE, D.A., WEBB, J.L. and SHINE, R., 2011. Removing forest canopy cover restores a reptile assemblage. Ecological Applications, vol. 21, no. 1, pp. 274-280. http://dx.doi.org/10.1890/09-2394.1. PMid:21516904.

PINO, J., RODÁ, F., RIBAS, J. and PONS, X., 2000. Landscape structure and bird species richness: implications and conservation in rural areas between natural parks. Landscape and Urban Planning, vol. 49, no. 1-2, pp. 35-48. http://dx.doi.org/10.1016/ S0169-2046(00)00053-0.

POWELL, S., COSTA, A.N., LOPES, C.T. and VASCONCELOS, H.L., 2011. Canopy connectivity and the availability of diverse nesting resources affect species coexistence in arboreal ants. Journal of Animal Ecology, vol. 80, no. 2, pp. 352-360. http:// dx.doi.org/10.1111/j.1365-2656.2010.01779.x. PMid:21118199.

R DEVELOPMENT CORE TEAM, 2013 [viewed 13 December 2013]. $R$ : a language and environment for statistical computing [online]. Vienna: R Foundation for Statistical Computing. Available from: http://www.rproject.org
RIBAS, C.R. and SCHOEREDER, J.H., 2007. Ant communities, environmental. characteristics and their implications for conservation in the Brazilian Pantanal. Biodiversity and Conservation, vol. 16, no. 5, pp. 1511-1520. http://dx.doi.org/10.1007/s10531-006-9041-x.

RIBAS, C.R., SCHOEREDER, J.H., PIC, M. and SOARES, S.M., 2003. Tree heterogeneity, resource availability, and larger scale processes regulating arboreal ant species richness. Austral Ecology, vol. 28 , no. 3, pp. 305-314. http://dx.doi.org/10.1046/j.14429993.2003.01290.x.

RICKLEFS, R.E. and SCHLUTER, D., 1993. Species diversity in ecological communities: historical and geographical perspectives. Chicago: University of Chicago Press.

ROSUMEK, F.B., 2008. Associação de Eremanthus erythropappus (DC.) McLeish (Asteraceae) com formigas e sua relação com a mirmecofauna do solo em floresta de altitude, região central de Minas Gerais. Lundiana, vol. 9, pp. 41-47.

ROSUMEK, F.B., SILVEIRA, F.A.O., NEVES, F.S., BARBOSA, N.P.U., DINIZ, L.L., OKI, Y., PEZZINI, F., FERNANDES, G.W. and CORNELISSEN, T., 2009. Ants on plants: a meta-analysis of the role of ants as plant biotic defenses. Oecologia, vol. 160, no. 3, pp. 537-549. http://dx.doi.org/10.1007/s00442-009-1309-x. PMid:19271242.

SANTOS, M.F., SERAFIM, H. and SANO, P.T., 2011. Fisionomia e composição da vegetação florestal na Serra do Cipó, MG, Brasil. Acta Botanica Brasílica, vol. 25, no. 4, pp. 793-814. http://dx.doi. org/10.1590/S0102-33062011000400007.

SCHMIDT, F.A., RIBAS, C.R. and SCHOEREDER, J.H., 2013. How predictable is the response of ant assemblages to natural forest recovery? Implications for their use as bioindicators. Ecological Indicators, vol. 24, pp. 158-166. http://dx.doi.org/10.1016/j. ecolind.2012.05.031.

SCHOEREDER, J.H., SOBRINHO, T.G., RIBAS, C.R. and CAMPOS, R.F., 2004. Colonization and extinction of ant communities in a fragmented landscape. Austral Ecology, vol. 29, no. 4, pp. 391-398. http://dx.doi.org/10.1111/j.1442-9993.2004.01378.x.

SCOLFORO, J.R., OLIVEIRA, A.D. and DAVIDE, A.C., 2007 [viewed 19 November 2011]. Sistema de manejo para a Candeia (Eremanthus erythropappus e Eremanthus incanus) [online]. Available from: http://www.nucleoestudo.ufla.br/nemaf

SILVESTRE, R. and SILVA, R.R., 2001. Guildas de formigas da Estação Ecológica Jataí, Luiz Antônio - SP: sugestões para aplicação domodelo de guildas como bio-indicadores ambientais. Biotemas, vol. 14, pp. 37-69.

STEIN, A., GERSTNER, K. and KREFT, H., 2014. Environmental heterogeneity as a universal driver of species richness across taxa, biomes and spatial scales. Ecology Letters, vol. 17, no. 7, pp. 866-880. http://dx.doi.org/10.1111/ele.12277. PMid:24751205.

TEWS, J., BROSE, U., GRIMM, V., TIELBÖRGER, K., WICHMANN, M.C., SCHWAGER, M. and JELTSCH, F., 2004. Animal species diversity driven by habitat heterogeneity/diversity: the importance of keystone structures. Journal of Biogeography, vol. 31, no. 1, pp. 79-92. http://dx.doi.org/10.1046/j.0305-0270.2003.00994.x.

VIANA-SILVA, F. and JACOBI, C., 2012. Myrmecofauna of ironstone outcrops: composition and diversity. Neotropical Entomology, vol. 41, no. 4, pp. 263-271. http://dx.doi.org/10.1007/ s13744-012-0045-9. PMid:23950060.

WALSH, C. and MACNALLY, R., 2013 [viewed 13 December 2013]. Package hier.part [online]. Available from: http://cran. stat. unipd.it 